\title{
ENKELE ASPEKTE VAN VRYHEID EN VERANTWOORDELIKHEID VAN DIE UNIVERSITET*
}

Meneer die Vise-Kanselier, Dames en Here,

By hierdie geleentheid vra ek $u$ welwillende aandag vir die onderwerp: „Enkele aspekte van vryheid en verantwoordelikheid van die universiteit".

1.

Die tweede helfte van die $20 \mathrm{e}$ eeu word met baie name genoem: die eeu van die natuurwetenskap, van die atoom, die kernkrag, ruimtevaart, ook selfs van die universiteit, en daarmee word dan telkens 'n tipering gegee van die tydperk ooreenkomstig die invloed wat daarvan uitgaan. Dat daar in ons tyd so 'n verskeidenheid van tiperinge bestaan, is wel seker 'n aanduiding van die kompleksheid van die situasie waarin die wêreld verkeer.

Die tweede wêreldoorlog was die knooppunt van die voorafgaande ontwikkeling wat die koers aangegee het vir ons tyd wat by oppervlakkige beoordeling voorkom asof daar ' $n$ totale breuk met die eerste helfte van die eeu gekom het. So fenomenaal was die ontwikkeling op haas elke terrein van die lewe dat so 'n eerste oogopslagbeoordeling nie as so dwaas voorkom nie. Dit sou 'n onbegonne taak wees om van hierdie ontwikkeling 'n inventaris te probeer maak; selfs as dit moontlik was, bly dit nog 'n vraag of dit meer sal wees as 'n blote oerwoud van feite en gebeurtenisse waarin dit die uiterste spesialisasie en ensiklopediese kennis sal vereis om daarvan sin te maak.

En tog word die akademikus kragtens die aard van

\footnotetext{
* Intreerede van prof. dr. H. J. J. Bingle by sy ampsaanvaarding as Rektor van die Potchefstroomse Universiteit vir C.H.O., gelewer op 14 Februarie 1964.
} 
sy werk geroep om steeds te soek na die samehang en betekenis van die wêreldgebeure, eers in hulle partikuliere verskyninge en daarna in hulle globale verband wat bydra tot die aanskyn van die geheel. M.a.w. die wetenskaplike van alle tye moet die fenomena van die kosmos nie alleen intrinsiek navors en beoordeel nie, maar ook in hulle onderlinge verband en in die tydsgewrig waarin hy leef, omdat die bepaalde wêreldkonstellasie aan hierdie verskynsels steeds 'n besondere kleur gee al sou dit die inherent-wesentlike daarvan nie radikaal verander nie; en ten slotte moet hy alles nog in hulle transendente verband plaas.

Alle aspekte van die kosmos word nie deur die historiese tyd ewe veel beïnvloed nie, maar wat in die tyd ontdek word op letterlik alle terreine van die skepping laat sig geld op 'n veel breër gebied as die eie - die een meer, die ander minder. En na gelang dié invloed toeneem, word dit steeds sigbaarder, eers net vir die kundiges in die wetenskap en daarna ook vir die oningewydes. So ervaar ons tyd by uitnemendheid dat die natuurwetenskap en tegniek reeds sulke vlugte geneem het dat selfs die kinders daaroor praat. Dit is tog so dat die prestasies op hierdie gebied hulle vroeg en laat aan elkeen opdring, hoofsaaklik omdat hulle in hulle uitwerking op die alledaagse lewe so sterk tot die sintuie spreek. Watter voordele en/of probleme hierdie posisie van die natuurwetenskap en die tegniek inhou, is nie nou ter sake nie; ek haal slegs die feitlike posisie aan.

Een ding is egter seker en dit is dat hicrdic koersbepaler van die hedendaagse lewe ver en wyd en diep tref. Dit gee nie slegs beter en dus gevaarliker krygstuig, besondere nywerheidsprodukte en 'n eie soort gerief en vermaak nie, maar dit beïnvloed selfs die menslike denke en geloof. Dit ruk aan die deure van die verborge grond van die menslike bestaan, want hier is versteurde verhoudings, nie omdat dié dinge ontdek en ontgin word nie, maar omdat die mens nie reg daarteenoor ingestel is nie. Ons geagte Eerste Minister het bv. vir hom 'n Wetenskaplike Adviesraad benoem wat eintlik natuurweten- 
skaplik bedoel om te wees, maar so belangrik is die invloed van die natuurwetenskappe beskou dat hulle in hierdie benaming die monopolie op die term wetenskap verkry het. Daar is van owerheidsweë 'n Wetenskaplike en Nywerheidsnavorsingsraad onder sy eie wet in die lewe geroep los van die staatsdiens en met enorme bedrae geld tot sy beskikking - hier weer die monopolie op die term wetenskap. Daar bestaan wel 'n Nasionale Raad vir Sosiale Navorsing - sonder die woord wetenskap in sy benaming - maar gewoon onder die staatsdiens en met seer geringe fondse tot sy beskikking.

Hier is versteurde verhoudings, want wie nog nugter in die moderne chaos kan oordeel, moet Woodburne dit gelyk gee as hy sê: „In fact, the new solutions and the more comprehensive explanations and more needed in the area of social interaction and human values than in any field of science. The solution of problems of human interaction in community life, national affairs, and international relations is, in fact, primary for a continuation of our civilization. And yet here is the very area where faculty members are warned against making constructive suggestions for improvement".

Vraagstukke van hierdie aard kan sonder moeite vermenigvuldig word - dink maar aan rasseverhoudinge en internasionale sake - maar genoeg om aan te toon dat daar inderdaad wanverhoudinge bestaan in die herkenning en belewing van die wêreldpatroon wat m.i. die resultaat is enersyds van die bruikbaarheid van een aspek van die wetenskap en andersyds van 'n bepaalde lewensbeskouing en lewenshouding wat sy agtergrond en rigting vind in die universitêre lewe van ons tyd. En hiermee staan ons voor 'n ernstige vraagstuk wat sonder twyfel besig is om koers aan die lewe te gee wat 'n kleine dertig jaar gelede nog in 'n totaal ander rigting beweeg het. In sy diepste grond kom die vraagstuk vir my daarop neer dat die universiteit en die leiers wat hy voortbring op grond van die vryheidsgedagte wat hulle huldig sekere kernverantwoordelikhede òf nie ken nie òf willens en wetens verontagsaam. 
Ek vra dan nou u aandag vir enkele aspekte van die vraagstuk van vryheid en verantwoordelikheid van die universiteit.

2.

Om ons probleem enigsins tot sy reg te laat kom, is dit nodig om vooraf te let op die posisie en funksie van die universiteit in die moderne tyd.

Sir Eric Ashby gee die volgende kernagtige tipering van die universiteit: „The ecology of universities is remarkable: they reach back to the middle ages and they girdle the Earth. From the plains of Lombardy they have been transplanted to the grey climates of northern Europe, to the African bush, to American cities. They have invaded the ancient civilisations of Egypt and India and driven out institutions deeply rooted in the indigenous culture. They have adopted themselves to totalitarian and to democratic societies, to rural communities and to urban technologies. But through time and space they have preserved something resembling a genetic unity: they remain unique as instruments for investment in man". Mallet stel hulle in betekenis op gelyke voet met die keiserryk en die pousdom as die skitterendste skeppings van die genie van die Middeleeue, terwyl Haskins hulle in belangrikheid as die eweknie van die katedraal en die parlement sien.

Dit staan vas dat die universiteit al eeue lank as die krag in die Westerse beskawing figureer, alhoewel dit dikwels langs verborge en indirekte weë gaan.

Uit die funksies van die universiteit blyk duidelik wat die invloed is wat daarvan kan uitgaan en inderdaad uitgegaan het.

Reg van die ontstaan van die universiteit af was dit 'n wesenstrek daarvan dat dit 'n inrigting vir geleerdheid is, vir die beoefening van die wetenskap. Hieronder is deurentyd min of meer dieselfde verstaan, al is daar in die moderne tyd tot ' $n$ omvattender en gesistematiseerder analise en sintese daarvan gekom. In hoofsaak kom dit 
hierop neer dat die universiteit hom wesentlik besig hou met ondersoek. Hy wil die waarheid binnedring, vir hom ' $n$ beter beeld van die werklikheid vorm, sonder bybedoelinge as net om die lewe, die maatskappy in die volle sin van die woord te dien. Dit doen die universiteit deur tegelyk die jeug op tweevoudige wyse op te lei, nl. tot die selfstandige beoefening van die wetenskap en tot die vulling van ampte en betrekkinge; dit is ook 'n instelling van onderrig. Die student word ontwikkel en gevorm na die intellek om diensbaar te wees vir alle beroepe waarin daar besonderlik na die verstandelike vermoëns van die mens gevra word. Uit die aard van die saak is die universiteit dus ook 'n inrigting wat algemene onderwys en opvoeding bewerkstellig, omdat die intellek nie van die persoon as geheel losgemaak kan word nie. So kan dan tot die slotsom gekom word dat in laaste instansie al sou dit nie die vooropgesette doel wees nie - die universiteit die leiers aan die gemeenskap verskaf. Watter standpunt dus oor die wetenskap, oor die mens, die wêreld, die lewe en in sonderheid oor vryheid veral op die terrein van die universiteit aan hulle voorgehou word, is van die grootste betekenis vir die toekoms van 'n volk. Ons beperk ons hier tot die laaste van die bostaande aspekte: vryheid en die verantwoordelikheid wat dit meebring, en dan nog slegs enkele aspekte daarvan.

\section{3.}

Die vraagstuk vryheid en die universiteit het 'n hele aantal aspekte: dit gaan oor die vryheid van die dosent, die van die student, van dic universiteit as geheel en soms word daar nog gepraat van die vryheid van die wetenskap ook. In hierdie verband word daar 'n verskeidenheid terme gebruik: akademiese vryheid, intellektuele vryheid, universitêre vryheid, universitêre outonomie. Gebrek aan ruimte maak dit onmoontlik om op die verskillende fasette van die vraagstuk afsonderlik in re gaan; die bedoeling van hierdie voordrag vereis dit ook nie, en daarom word almal gesamentlik kortliks benader.

In Bologna (iewers in die 12e eeu) het die studente 
hulle aan daardie Studium Generale in Universitates ge organiseer om hulle belange te beskerm teen die stadsbewoners. ('n Universitas was 'n assosiasie in die destydse geleerde wêreld wat ooreengekom het met 'n gilde in die kommersiële wêreld, 'n unie van manne wat in 'n Studium saamgeleef het en wat sekere gemeenskaplike belange gehad het wat beskerm en bevorder moes word. Die woord „universitas" het dus glad nie die betekenis van ons universiteit van vandag gehad nie - Studium Generale is eintlik die sinoniem van ons universiteit. Dieselfde Studium Generale het soms meer as een universitas gehad. In die Studium Generale van Parys het die Universitas uit dosente bestaan. Daar is gevalle bekend waar die Universitas opgepak en die stad verlaat het as hy nie sy sin kry nie en dan die Studium Generale met hom saamgeneem het na ' $n$ ander stad - iets wat maklik kon gebeur omdat die inrigting nie aan geboue gebind was nie). Nadat die studente die saak teen die stadsbewoners van Bologna gewen het, het hulle hulle teen hulle natuurlike vyand gewend, $\mathrm{nl}$. die professore. Hulle metode was die boikot, en aangesien die professore van hulle geld afhanklik was, was hulle dreigemente sukses. vol. Hulle het mettertyd selfs reëls vir die professore opgestel waarin o.a. voorgekom het dat hulle nie mag afwesig wees sonder verlof nie, selfs nie vir een dag nie. Hierteenoor het die dosente ook hulle gilde of universitas in die lewe geroep om hulle belange te beskerm. Toegang tot hulle gilde is alleen verkry deur 'n eksamen wat aan die suksesvolle kandidaat die licentia docendi, d.w.s. sertifikaat om onderrig te gee, besorg het.

Die professore het nie intellektuele vryheid, nl. om die waarheid te onderrig soos hulle dit gesien het (wat ons vandag ook akademiese vryheid noem) geniet nie, omdat die Middeleeue oor die algemeen die opvatting gehuldig het dat waarheid iets is wat alreeds geopenbaar is aan ons deur outoriteit, en dat dit slegs uiteengesit moet word getrou aan die outoritatiewe leerstellinge. Dit was die algemene situasie. In die praktyk was daar egter vryheid van diskussie en onderrig in die vakke wet, medi- 
syne, grammatika en wiskunde maar nie in filosofie en teologie nie, omdat hulle "gevaarlike" vakke was wat die kerk kon benadeel.

So vroeg as die $13 \mathrm{e}$ eeu reeds het konings, keisers en pouse Studia opgerig of spesiale voorregte aan bestaandes verleen, sodat dit spoedig gebruik geword het dat 'n skool wat die status van Studium Generale geëis het die outoriteit van die koning, keiser of pous moes verkry.

Met hierdie heel vroeë ontwikkeling van die universiteit het die vryheidsvraagstuk reeds in al sy aspekte na vore gekom, die van die dosent, die student en die inrigting as geheel, en reg van die begin af was die meningsverskil oor wat dit behoort te wees ook daar. Vandag dryf party akademici die spot daarmee deur akademiese vryheid te bestempel as "the right to say what one thinks without thinking what one says", ander beskou dit as die hoogste besit van die universiteit; party beweer dat claar absolute vryheid kan en behoort te wees, ander beskou dit as selfbedrog om te meen dat daar so iets kan bestaan.

In hierdie verband is Dwight $\mathrm{L}$. Bolinger baie uitgesproke en na ons mening korrek as hy sê: „Every course of existence - a political system, a religion, a code of table manners, a set of food habits - imposes itself and makes unbiased judgment impossible. Complete intellectual freedom exists in the imagination of administrators on special occasions, such as the laying of cornerstones and appearances before boards of regents, but at no fixed or movable point in the real world". Ten opsigte van die vraagstuk van intellektuele vryheid klassifiseer hy die akademici volgens hulle gedrag in drie groepe:

a. Diegene wat van nature of as gevolg van hulle opvoeding so afsydig staan van gemeenskap met hulle medemense dat hulle byna-byna vry is. Geen inrigting sal hulle wil hê nie, want hulle is bereid om in dieselfde asem engele en duiwels te verdedig.

b. Diegene wat onvry is en dit nie wil erken nie - hulle is die hipokriete, die skynheiliges wat hulle seile na die wind span. 
c. Diegene wat onvry is en dit erken. Dis hulle wat volgens die drywers van intellektuele vryheid uit die akademie geskop moet word omdat hulle sogenaamd blind is as gevolg van hulle keuse. In der waarheid is hulle egter die minste bedreiging vir intellektuele vryheid. Intellektuele vryheid het drie groot komponente: intellektuele eerlikheid, intellektuele moed en intellektuele indifferentheid. Hulle besit die eerste twee hiervan, die laaste een nie maar is gedurig bewus daarvan en daarom kan hulle dit steeds in gedagte hou en daarvoor toegee. Diegene wat onder hulle sorg is, weet ook wat hulle aan hulle het.

In hoofsaak kom dit hierop neer dat die wêreldmening in twee groot kampe verdeel kan word wat die opvattinge oor vryheid van die universiteit betref:

1) Die groot meerderheid wat vir die universiteit die reg opeis om al sy sake selfstandig te hanteer, om leervryheid te beoefen en om geen bepaalde gemeenskaplike belydenis te hê nie, om in alles los te wees van enige bindende mag of krag of beginsel van watter aard ook al. Eintlik word vryheid hier sinoniem met losbandigheid, bandeloosheid, willekeurigheid, ongebondenheid.

2) As 'n veel geringer groep staan hierteenoor diegene wat vryheid as 'n relatiewe begrip in alle verbande met die universiteit sien, wat nêrens absolute vryheid aanvaar nie. Orals is daar bande al is hulle baie uiteenlopend van aard. Hieronder val o.a. die opvattinge van die totalitariese state, die Rooms-Katolieke en ook die Calviniste.

Hoe sien die Calvinis dan hierdie vryheid? Omdat die Gereformeerde deurentyd die onderwys in al sy vertakkinge as ' $n$ belangrike saak vir die gelowige beskou het, was waar ook steeds die leiers op hierdie terrein wat as verdedigers van 'n bepaalde siening van dié vryheid opgetree het. Omdat Nederland die eksponent by uitnemendheid van die Calvinisme was, spreek dit vanself dat dit ook Nederlanders sou wees wat dié bepaalde vryheidsgedagte in die onderwys sou verdedig. Ons dink hier aan 'n lang ry leiers: Groen van Prinsterer, Kuyper, 
Woltjer, Bavinck, Waterink o.a. Maar ook ons land het sy manne gelewer wat hierdie vaandel gedra het: o.a. F. Postma, J. D. du Toit, J. Kamp, J. Chr. Coetzee, H. G. Stoker. So sterk is die saak van vryheid gevoel dat dit selfs die lewensvoorwaarde vir die hoër onderwys genoem is.

Prof. Stoker maak onderskeid tussen akademiese vryheid en universitêre vryheid en wel so dat eersgenoemde veel beperkter as laasgenoemde is. Onder akademiese vryheid verstaan hy die vryheid om te bepaal wat die akademiese vereistes vir toelating van studente is, vir die verwerwing van grade, vir aanstelling van die personeel, en die vryheid van navorsing en onderrig sousel as interne organisasie. Die belangrikheid (selfs vanselfsprekendheid) van akademiese vryheid vereis geen betoog nie. Universitêre vryheid sluit al die bostaande in, maar dit gaan ook nog verder en behels o.a. die vryheid om leiers vir 'n verskeidenheid sfere van die menslike lewe op te lei, en meer bepaald lede van die hoër beroepe; om ten volle deel te neem aan, om 'n konsentrasiepunt te wees, 'n leier sowel as ' $n$ dienaar van die kultuur van 'n land. Essensieel vir universitêre vryheid is ' $n$ intieme band met die ander betrokke groepe van die land, omdat alle vryhede onderling afhanklik is. Universitêre vryhede in hierdie gevalle kan nie geïnternasionaliseer word nie. Hieroor bestaan daar meningsverskil.

Maar hy kom tot nog 'n derde aspek van hierdie vryheidsvraagstuk, wat hy intellektuele vryheid noem en wat per slot van sake inskakel by menslike vryheid in die breë. En dis juis op hierdie terrein van die vryheid waar die Gereformeerde beskouing hom geheel en al onderskei van die ander wat ook vryheid begeer, maar 'n vryheid van 'n ander aard.

Om die eie opvatting oor wat vryheid op hierdie terrein inhou, is die Calvinisme dikwels daarvan beskuldig dat hy vooringenome is en dus intellektueel onvry. Hierteenoor verdedig Stoker sy saak: „Intellektuele vryheid (reg verstaan) is ...'n vooraanstaande beginsel van 
die Kalvinisme. Dit neem 'n ere-plaas in naas die beginsel van geloofsvryheid, van gewetensvryheid, van nasionale vryheid, van kringsvryheid (soewereiniteit in eie kring) waarvoor die Kalvinisme al 'n eeue-oue stryd gestry het. Die Kalvinisme is ware vryheidsleer".

Nadat hy dan daarop gewys het dat intellektuele vryheid nie ongebondenheid, bandeloosheid, willekeurigheid in die denke kan wees nie, maar juis gebondenheid aan die waarheid, die orde, die wet wat die denke wil ontdek en ken, verwerp hy eweneens die gedagte dat vryheid outonomie, selfbepaling, selfbeskikking wat noodwendig op vryheidsvergoddeliking moet uitloop, kan wees, omdat vryheid juis onderworpe is aan die ordinansies van God, aan die objektiewe gegewe en geopenbaarde waarheid - saamgevat as diens, onderworpenheid en gebondenheid; maar vryheid is ook nog tegelyk onathanklikheid en afhanklikheid: onafhanklikheid van mense, afhanklik van die waarheid soos in die natuur verwesenlik en in die Skriftuur van Godsweë geopenbaar. So kom hy dan tot die slotsom: Intellektuele vryheid is waarheidsdiens sowel t.o.v. Gods Woord as t.o.v. Gods skepping. Alle vryheid is in wese ordelik en wetmatig, anders is dit willekeur. Die diepste sin van alle skepsele is Godsdiens, en in hierdie diens vind hy sy hoogste bevoegdheir en ware vryheid. Tot die diepste fundering van dié vryheidsgedagte kom Stoker as hy dit grond in die menslike vryheid in sy horisontale en vertikale verband: horison. taal in die skepping as heerskappy waarin menslike vryheid nie teenoor wet staan nie, maar teenoor slawerny, waaruit voortvloei die gedagte van skepping (kultuurskepping), vryheid as heerskappy, skepping wat egter kosmies-onties beperk is. So beheers die wetenskaplike o.a. sy stof van ondersoek, sy metodes, sy denke en kenne, sy verifikasie en teoriebou; heersend begryp, beskryf, verklaar, verstaan en beoordeel hy, aanvaar hy veronderstellings; dit is sy vryheid, maar as hy beheers word deur vooroordele is hy onvry, slaaf; vertikaal as onselfgenoegsame wese in sy binding aan God, die algenoegsame en absolute Grond van die héle kosmos met al sy moontlik- 
hede, behorenseise én menslike vryheid; sonder die Goddelike almag is die menslike vryheid nie te verstaan nie; as beelddraer van God besit die mens dus ook vryheid, maar slegs relatiewe vryheid in onderworpenheid aan die wet van God.

Bring ons nou hierdie seining terug na die universiteit met al sy fasette van vryheid, kom ons tot die slotsom dat vryheid hier bestaan uit die hoogste gebondenheid aan die wet van God soos geopenbaar in Skriftuur en natuur; dit gee die element van die mens waarin hy bedoel is om te leef; gaan hy daarbuite is hy slaaf, sterf hy geestelik.

4.

Wie hierdie verhewe standpunt oor die vryheid op universitêre vlak aanneem, aanvaar onmiddellik 'n ontsettende verantwoordelikheid, ontsettend in die sin dat geen mens dit uit homself kan dra nie. Dis om van te huiwer as 'n mens dink aan die veelvuldigheid van die heerskappy waarvoor verantwoording gedoen sal moet word. Wie die vryheid sien as 'n ongebondenheid waarin onbeperkte mag verleen word, skrik nie hiervoor terug nie want hy aanvaar die mens as 'n almagtige wese, en daarom is hy dit ook; die gelowige huiwer omdat hy die beperkinge van die mens ken, maar hy aanvaar die verantwoordelikheid dankbaar omdat hy weet dat $\mathrm{Hy}$ wat roep die Gewer van die vryheid is en ook van die krag om dit in sy Naam uit te leef.

Die vryheid van die universiteit bring verantwoordelikheid vir alle terreine van die universiteit mee: organisatories wat sy oprigting, instandhouding en beheer betref, sowel as wesentlik wat die vryheid van die beleid, van leraar en student, van wetenskapsbeskouing, navorsing, onderrig, beroepsvoorbereiding, gemeenskapsdiens, nasiediens, godsdiens betref. En dit hang van die volvoering van hierdie taak af watter koers die invloed van die universiteit sal neem in die maatskappy, die volkslewe en die internasionale verband; dit sal bepaal watter lewens- 
houding geskep sal word, watter waardes gehuldig sa! word, watter toekoms daar ook vir die Republiek van Suid-Afrika vorentoe lê. Op enkele van hierdie aspekte moet nou nader ingegaan word.

\section{Organisatories:}

As die universiteit waarlik vry is, lê dit die verpligting op hom sy stelsel van beheer in lyn daarmee in te rig. In die universitêre wêreld van vandag is daar 'n verskeidenheid soorte beheerliggame: in party gevalle is dit die staat, in ander die kerk, in nog ander 'n korporasie van belangstellendes en/ol belanghebbendes en ten slotte in variasies van saamgroeperinge van die genoemde instansies. Die reël in ons land is 'n bepaalde saamgroepering van verskillende instansies.

Omdat die P.U. vir C.H.O. op die hierbo gestelde standpunt oor die vryheid staan, beskou hy dit as sy verantwoordelikheid om die beheer van die universiteit soos volg te sien.

Die beheer van die universiteit is in die hande van die Raad. Die samestelling van die Raad is van die uiterste belang vir die handhawing van 'n bepaalde faset van die vryheid van die universiteit. Hierin is wat ons universiteit betref die volgende vyf instansies opgeneem: die staat, die trustees van die Gereformeerde Kerk, die gevolmagtigdes van die oorspronklike oprigters, donateurs en die konvokasie en die Senaat, wat eintlik daarop neerkom dat daar vier samelewingsvorme hierby betrokke is: die staat, die kerk, die belanghebbendes in die maatskappy en die dosente. Die universiteit lê op die terrein van die maatskappy en in die moderne samelewing beklee dit kragtens sy aard en funksie 'n heel besondere plek. Dit is 'n eie entiteit wat optree in 'n eie kring, op 'n eie terrein en volgens 'n eie metode. En tog het die bogenoemde samelewingsvorme belang daarby. Van die verhouding van hierdie samelewingsvorme tot die universiteit sal dit afhang of die universiteit vry is of nie; word hy deur een van hulle oorheers, is hy die slaaf van daardie samelewingsvorm. Die universiteit staan tussen hulle 
maar as eiesoortige en vrye instelling: hy is na sy aard en wese die dienaar van almal en tog nie die slaaf van een van hulle nie. Die universiteit is dus vry maar ook gebonde. Eers wanneer hierdie verhouding reg staan, kan van 'n vry universiteit in organisatoriese sin gepraat word.

Al die belanghebbende samelewingsvorme by die universiteit vorm in die universiteit 'n nuwe eenheid waarvan die wese nie beskou kan word as die somtotaal van die wesenstrekke van almal nie, omdat elkeen van daardie samelewingsvorme nog ander hoedanighede en funksies ook besit wat met die universiteit as sodanig niks te maak het nie. Aan die ander kant is dit ewe duidelik dat hierdie nuwe eenheid geen hoedanighede of beginsels in hom kan hê wat bots met die wat hy dien nie. In die universiteit kom die genoemde vier saam in 'n nuwe samelewingsvorm met sy eie aard en wese wat in al vier saam gefundeer is. Elkeen van die vier samelewingsvorme is dus by letterlik alles in die universiteit betrokke.

Maar die universiteit staan ook in verband met die ander inrigtings vir hoër onderwys in die land, en dit is noodsaaklik dat hulle almal sal saamwerk in die taak van voorsiening van tertiêre onderwys. Vir hierdie doel bestaan daar dan ook 'n gemeenskaplike universiteitswet vir die blanke inrigtings waardeur die sake van gemeenskaplike belang gereël word. In hierdie verband kom in die wet vir sover dit die P.U. vir C.H.O. raak niks voor van 'n prinsipiële aard wat sy vryheid aantas nie, terwyl dit nie die geval was voor ons selfstandigwording nie. Ek bedoel die sg. gewetensklousule, waarvolgens die universiteite nie vry is om te vra na die geloofsoortuiging van kandidate by die benoeming van dosente nie. In hierdie saak gaan dit ten volle om die vryheid van die universiteit om ' $n$ bepaalde belydenis te mag huldig. Die gewetensklousule huldig ook 'n belydenis en wel die liberalisme, en dit is wetlik so voorgeskryf. M.a.w. hierin vind ons die situasie dat die wetgewer vir die universiteit voorskryf en die universiteit dus nie heeitemal vry is nie - hy is dan in ' $n$ sin die slaaf van een van die belanghebbende samelewingsvorme. 
Deur die gewetensklousule word die universiteit in beginsel onder die wet van God uitgelig deurdat dit teen die ordinansies van God ingaan en onder 'n ander wet, die wet van die mens, geplaas; en verder word daardeur van die universiteit verwag om ook teen die wet van die skepping in te gaan, wat 'n fisiese en psigiese onmoontlikheid is, nl. dat hy moet doen wat hy nie in staat is om te doen nie.

Die bepaalde vryheidsbeginsel hierbo bespreek, het op ons voorgangers 'n groot verantwoordelikheid gelê wat hulle met eer gedra het, en dit lê op ons geslag die ewe groot verantwoordelikheid om te bewaar wat verkry is en daarmee een van die tiperende verskynsels van ons tyd positief te beveg, nl. om dubbelslagtigheid in die menslike denke te kweek deur beginsel en praktyk in botsing teen mekaar te aanvaar en selfs te verdedig. Regte lewensperspektiewe in die volkslewe, d.w.s. vergesigte wat in lyn met die volksverlede lê, is een van die kragtigste invloede wat van 'n universiteit kan uitgaan as hy- waarlik mede-bouer aan die kultuur van die land wil bly.

Die geslag van die toekoms moet toesien dat die universiteit nie in sy beheer deur een of ander instansie oorheers word nie.

In die voorgaande voorbeeld van oorheersing het dit gegaan om die gees en rigting van die universiteit. Ek wil nog 'n terrein noem waarop die vryheid van die universiteit maklik in die gedrang kan kom, en dit lê op die gebied van die instandhouding van die universiteit. Die verantwoordelikheid lê by die Raad van die universiteit om toe te sien dat hy nie geheel en al van die staat afhanklik word vir die instandhouding van die universiteit nie. Maar dit is ook 'n verantwoordelikheid van die belanghebbende gemeenskap, indien hy nie later tot die ontnugtering wil kom dat 'n besondere kleinood tussen sy vingers deur geglip het nie. Wie die universiteit in stand hou, beheer hom ten slotte.

Die wesentlike in die universiteit:

In al die werk van die universiteit moet daar positief 
na vore getree word ter uitbouing van wat wesentlik is en alle moontlike skadelike weë moet bekamp word.

a) Die universiteit is na sy wese in die eerste plek 'n inrigting waarin die wetenskap beoefen word. Dit kom in die praktyk neer op navorsing en onderrig wat deur dosent en student beoefen word. Hoedanig hierdie werk gedoen word, hang af van die wetenskapsbeskouing waarvan uitgegaan word. Onmiddellik kom die vraagstuk van die vryheid van dosent en student ter sprake. Die algemene beskouing van die universiteite oor hierdie saak is dat in wetenskaplike navorsing elke navorser vry is om te doen wat hy wil soos hy wil, of dat hy hoogstens hierin deur die fenomeen self gelei mag word, anders word sy vryheid aan bande gelê waardeur hy dan nooit by die waarheid sal uitkom nie; en verder dat dit nie wenslik, selfs nie moontlik is, dat 'n universiteit as geheel 'n wetenskapsbeskouing kan hê nie - dit sou die vryheid van die indiwidu (dosent en student) totaal vernietig. Ons vryheidsbeskouing gee hierop ons antwoord ondubbelsinnig waaroor ons slegs hoef op te merk dat daar volgens die wet van God - en alles in die skepping is aan hierdie wet onderworpe - en dié van die natuur - daar bestaan geen mens wat homself van sy bedrywighede (hier wetenskapsbeoefening) kan skei nie - geen neutrale wetenskap en dus ook geen neutrale universiteit kan wees nie; ook diegene wat dit ontken dat hulle of hulle universiteit ' $n$ belydenis of belydenisse het, is aan hierdie wet onderworpe.

As al die indiwidue wat aan die universiteit werk, staan in die vryheid waarvan ons hierbo gepraat het, dan kan hulle in korporasie ook nie anders nie. Daar kan dus geen sprake wees van dwang as die universiteit 'n belydenis het vir almal wat uit almal wat dieselfde is, opgebou is nie. Hiermee het ons nog glad nie wat die teëstander by voorkeur doodse eenvormigheid noem nie, want daar is geen sprake van dwang nie, en daarby word die wetenskap vanuit dieselfde grondslag uitgebou deur die persoonlike verskeidenheid na die variasie wat God 
in sy koninkryk en in die mens ingelê het - die verskeidenheid wat gegrond is in die gegewenheid. O.i. is dit ook die enigste grond vir die ordelike uitbouing van die wetenskap as geheel, wat gebalanseerdheid van beskouing oor die wetenskap en die lewe meebring en wanverhoudinge waarvan in die inleiding verneem is, verhoed.

Met hierdie beskouing oor die vryheid word daar groot verantwoordelikheid op die universiteit gelê daarin dat hy steeds moet waak dat dit beskerm word, dat dit nie sal ontaard in „uhuru" nie, dat die dosent gerus kan wees dat hy rustig mag voort gaan met sy godgegewe roeping.

Van die kant van die student gesien, is die vraag of ons nie hier te doen het met indoktrinasie van die ergste graad nie. Indoktrinasie is dit inderdaad dog alleen in sover alle opvoeding indoktrinasie is. Die student is vry om hierdie leer te verwerp. Onder die omstandighede soos aan ons Universiteit met sy bepaalde belydenis word hy nooit in die situasie geplaas dat hy met sy onrype oordeel moet kies uit 'n veelheid van wetenskapsbeskouings nie. Hy sal met baie te doen kry op wetenskaplike wyse sodat hy nie onkundig deur die universiteit gaan nie, maar sy onrype gees sal nie voor keuses gestel word wat hom te magtig is nie. Die Universiteit aanvaar dit as sy verantwoordelikheid om hom hierin reg te lei deur middel van sy verpligte kursusse in Studium Universale. Maar die Universiteit dra hierdie verantwoordelikheid ook met vreugde, want hy staan in diens van die Gereformeerde Afrikaner wat van sy ouerhuis af met daardie belydenis kom en hier op die universiteit die regverdiging van daardie beskouing in die wetenskap kom opdoen, wat hier 'n lewensfilosofie of lewens- en wêreldbeskouing naïef met hom meegebring, wetenskaplik kom grondves.

In sy wetenskapsbeoefening in navorsing en onderrig lei die universiteit wetenskaplike denkers op wat in 'n veelheid van beroepe gaan staan waar hierdie hoedanigheid ter sprake kom. Hy lewer mense aan volk en kerk; hy bou dus aan die nasionale kultuur skeppend en aan 
die Gereformeerde leer en lewe. En hierdie sake kan alleen gedien word as die geestelike leiers die volk reg voorgaan in beskouing oor wêreld en lewe. Groot is die verantwoordelikheid van die P.U. vir C.H.O. in hierdie verband sodat die bakens van die volk nie versit sal word nie en dat hy inderdaad Christelik-Nasionaal sal bly.

b) Maar in die beoefening van die wetenskap deur navorsing en onderrig dra die Universiteit ook die verantwoordelikheid gegrond in sy vryheidsbeskouing om hom op al die terreine van die wetenskap te beweeg en om vir al die relevante professies voor te berei. Alleen deur die wetenskap in al sy aspekte te beoefen, sal die wetenskaplike die volle betekenis van die kosmos begryp, vir sover dit begrypbaar is, sodat hy, volgens ons vryheidsbeginsel, werklik in vryheid en onderworpenheid heerser, kultuurskepper kan wees as kind van God. Maar ook die gemeenskap moet so gedien word voordat aan die verantwoordelikheid voldoen kan word. Daar is egter in albei gevalle beperkende magte, veral die materiële, wat dit nie altyd moontlik maak nie. Daar mag dus nie gerus word met die P.U. vir C.H.O. voordat al die basiese fakulteite hier ingestel is en al die relevante basiese beroepe aangebied word nie.

c) Ten slotte wys ek op nog 'n laaste terrein waarop die vryheidsbeginsel van die P.U. vir C.H.O. groot verantwoordelikhede lê, en dit is navorsing op die terrein van die universiteit self: oor die personeel, studente, curricula, sillabusse, die leerproses, metodes van onderrig en navorsing, geboue en toerusting, en dit alles steeds in diensbaarheid aan die vryheid van dosent, student, inrigting, maatskappy, volk en kerk. In 'n sekere sin is die draers van die groot beginsels en die wyse waarop dit gedoen word skromelik verwaarloos. Daar is ' $n$ standpunt dat die universiteit nie aan die kriterieë vir doeltreffendheid onderwerp moet wees nie, maar daar is tog seker vandag nie meer rede waarom navorsing i.v.m. die produksie van tertiêr opgevoede mense nie gedoen sal word nie; 
of is dit nog waar wat Ashby oor die akademici sê: ,Although dedicated to the pursuit of knowledge, they are reluctant to pursue knowledge about themselves"? In ons land staan ons waarskynlik voor baie belangrike ontwikkelinge op universitêre terrein, en waar daar sprake is van selfs nuwe inrigtings is dit slegs te betreur dat ons oor so weinig werklik wetenskaplik vasgelegde gegewens oor alle fasette van die Universiteit beskik - ook 'n saak van verantwoordelikheid!

Enkele aspekte word kortliks genoem:

(i) Die dosent is die spil waarom alles draai in die handhawing en uitbouing van die werk van die universiteit; die beginsels kan nog so verhewe wees, maar as die akademikus nie daar is om hulle te verwesenlik nie, kan daar letterlik niks van tereg kom nie. En wie bekommer hom nou werklik oor sy opleiding? Of indien indiwidue dit nog wel doen, waar bestaan die eenheidspatroon vir sodanige opleiding? Ons weet wel een en ander - party minder, ander meer - van hierdie opleiding maar dit is hoofsaaklik gegrond op sporadiese navorsing en/of veralgemeende indiwiduele ervaring.

Van die universiteitsdosent word beweer:

1. As indiwiduele akademikus dat hy

a. intellektueel baie superieur is; daar is ook ander professies waarvan dit gesê kan word; dit is 'n noodsaaklike maar nie 'n voldoende eienskap nie;

b. in die reël uit die middelklas huisagtergrond kom wat glo dat sukses in die lewe afhang van goeie onderwys en harde werk;

c. voorkeur kweek vir intellektueel prikkelende en sosiaal isolerende aktiwiteite; hy waardeer vryheid, onafhanklikheid, die geleenthede om te leer, genoeg geld om hom in staat te stel om eerbaar te leef.

2. As onderwyser-akademikus: oor die algemeen word nog geglo dat hy nie hoef geleer te word om te leer nie; oor die aard en voorwaardes van die leerproses is hy omtrent heeltemal onkundig, bv. oor programmering in die onderwys; van die beoordeling van die werk van 
student en dosent weet hy bedroef min, van die beoordeling van die onderrigwerk en van promosie.

3. As navorser: baie skep 'n kloof tussen onderrig en navorsing - party universiteite beklemtoon die een, ander die ander; daar bestaan die gevaar dat iets mistieks om navorsing geweef kan word omdat op daardie terrein in die jongste verlede soveel gepresteer is. Navorsing word per slot van sake gedoen om iets te leer, en daarsonder sal die kennis stagnant word - daar is selfs baie van die kennis van die verlede wat verouderd is en wat deur navorsing reggestel moet word. Met „publish or perish" word daar egter te ver gegaan.

4. As lid van die akademiese gemeenskap en van verenigings buite die universiteit: Hieroor weet ons betreklik min, maar wel dat hulle soms mekaar beveg op 'n onvrugbare wyse, dat hulle aan allerlei gebruike en prosedures kleef wat soms met die ywer van die fanatikus beoefen word; hulle skakel hulle soms in ordes saam wat selfs op internasionale vlak en omvang optree.

5. As lid van 'n volk en kerk: In die reël tree hy nie hier baie sterk na vore nie, maar as hy dit doen, verbrand hy dikwels sy vingers.

Hierdie opmerkings oor wat sogenaamd oor die akademikus bekend is, is genoeg om ons te laat besef dat aan hom groot onreg aangedoen word. Daar is besondere behoefte daaraan om werklik wetenskaplike kennis oor die akademikus te bekom - en dis 'n verantwoordelikheid wat die vryheidstandpunt van die P.U. vir C.H.O. sonder reserwe van homself eis.

(ii) Wat die student en sy opleiding betref, is die prent heelwat duideliker. In hierdie verband is meer navorsing gedoen, en word nog gedoen ook deur ons Universiteit. Hiermee staan ons egter ook nog maar aan die begin van wat werklik vereis word indien ons aan ons verantwoordelikheid wil voldoen. Om 'n enkele voorbeeld ter illustrasie te neem: Wie weet wat die belangrikste is: of om die student aan homself oor te laat in die eerste jaar sodat hy gemaak of gebreek word, ò om hom sodanig te help dat hy wel slaag maar soveel aan 
selfstandigheid verloor dat hy as 'n onbelangrike produk te voorskyn tree - as so iets wel moontlik is: ons weet dit nie!

(iii) Ten slotte wil ek net nog twee sake uit die vele na vore bring waaroor ons navorsing broodnodig het: die een lê op die terrein van die didaktiek en die ander op die van geboue en toerusting.

Navorsing i.v.m. onderrig en leer is besonder moeilik omdat studente sulke berugte aanpassers is: gee aan hulle minder les dan werk hulle self meer; pas 'n nuwe metode toe en hulle doen beter bloot as gevolg van die nuutheid daarvan. Daar word dan op grond van navorsing beweer:

1. dat die lesingmetode groter sukses met groot klasse as met kleineres behaal, al is dit dan net omdat die dosent hom beter voorberei vir 'n groter gehoor as vir 'n kleinere;

2. dat seminare en tutorials klein groepe moet hê, maar die vraag is hoe klein, want die bewering is al gemaak dat in party vakke 12 beter as 4 in 'n groep is;

3. dat studente beter eksamens doen wanneer hulle min onderrig ontvang as wanneer hulle ' $n$ oormaat daarvan kry;

4. dat daar genoegsame bewys is dat die toepassing van tegnologiese uitvindings in die onderrig beter resultate ook aan universiteite afwerp, al is daar nog baie akademici wat, net soos hulle baie ouer broers wat nie die skriftelike werk wou aanvaar i.p.v. mondelinge of die gedrukte eksemplare i.p.v. die een wat om die beurt deur almal gebruik moes word nie, ook nie die hulp van die radio, televisie, geprogrammeerde onderwys wil inroep nie.

Hier is ' $n$ terrein waarop die moontlikhede legio is en daarom is die verantwoordelikheid ewe onbeperk.

Die kapitaal wat aan terrein, geboue en toerusting aan universiteite bestee word, is fenomenaal. So is in Engeland bereken dat daar aan geboue en toerusting $R 4,800$ belê moet word vir 'n natuurwetenskapstudent en $R 7,000$ vir ' $n$ student in die tegnologie. Daar word dan ' $n$ 
berekening gemaak dat so 'n laboratorium vir baie min tyd gedurende die jaar werklik diens doen, veral in die geval van eerstejaars. Dat die syfers hier in ons land ook hoog sal wees, weet ons, en die vraag doen hom voor of dit nie ' $n$ noodsaaklikheid geword het om na te vors hoedanig hierdie saak gehanteer kan word om meerdere diens uit die hoë kapitale belegging te verkry nie. Dit geld natuurlik nie net laboratoria nie. Laat dit genoeg wees om te besef dat dit hier ook weer gaan om gebrek aan navorsing op dic terrein van die universiteit self.

5.

Om nou terug te keer na die uitgangspunt van hierdie voordrag: In haas alle fasette van die moderne lewe word verwag dat òf die naby òf die veraf leier in mindere of meerdere mate aan die universiteit verbind moes gewees het; al sou daar nog terreine wees waar hierdie eis nie gestel word nie - en hulle word al minder - dan kan sonder twyfel aanvaar word dat die posisies in die lewe wat rigtend vir die wel en wee van die mensdom is, gevul is met die produkte van die universiteite. Watter koerse daar dan aangegee word, kom uit die inrigtings vir hoër onderwys. En nou is ek van oordeel dat die mate waartoe hierdie leiers tot die ware vryheid gelei is, bepalend is vir die perspektiewe wat hulle sal huldig en bewerkstellig; daarvan sal afhang of die volgeling gebind sal wees aan die wet van God, en in ons geval aan die geskiedenis en aard van die volk wat 'n eie karakter onder daardie wet ontvang het. Ek hou my verder daarvan oortuig dat hierdie grondslag wanverhoudinge wat noodwendig moet ontstaan as die God-gebondenheid ingeruil word vir ' $n$ mensgebondenheid sal verhoed en 'n klare toekoms daar sal stel: laat wat die swaarste weeg die swaarste wees.

Dis ' $n$ heerlike beginsel om te bely hierdie, en mag die verantwoordelikheid wat dit meebring ewe heerlik deur die P.U. vir C.H.O. tot in lengte van dae gedra word! 
Hooggeagte Voorsitter en lede van die Raad,

$\mathrm{U}$ wat die verantwoordelikheid dra vir die beginsel van die vryheid wat die P.U. vir C.H.O. huldig, het my geroep om $u$ medestander in besondere $\sin$ in hierdie saak te wees. Hierdie beginsel vra saam met die skerpsinnigheid van die hoof die oorgegewenheid van die hart, ja, dit vereis 'n verborge verstaan met die hart, soos iemand gesê het, en wie dit bely, is voorwaar soos 'n brandhout uit die vuur geruk. As mede-gelowige betree ek die strydperk saam met $\mathbf{u}$ in die vaste vertroue dat Hy wat roep ook die krag sal gee vir die bevordering van sy koninkryk midde in dic volk waarin $\mathrm{Hy}$ ons geplaas het. Dié vertroue in my gestel, waardeer ek ten seerste.

Hooggeleerde Dame en Here van die Senaat,

$\mathrm{U}$ wat met verantwoordelikheid die uitbouers is van die beginsel van die vryheid wat deur hierdie Universiteit bely word, het my aanbeveel vir benoeming om $u$ in hierdie groot taak dienend te lei. Dit aanvaar ek met dank en vrymoedigheid omdat ek weet dat waar my diens en leiding mank gaan $u$ mede sal lei want dit gaan hierin vir ons almal steeds om die eer van God en nie om die van mense nie. Ek bied $u$ hart en hande, ek vra $u$ geduld en ondersteuning sodat ons saam kan staan in die vryheid waarmee Christus ons vry gemaak het.

Geagte Dames en Here, ek dank $u$ vir $u$ gehoor.

Ek het gesê.

BIBLIOGRAFIE:

ASHBY, Sir Eric:

(a) Investment in Man. New Scientist. Vol. 19, No. 354, 29 August 1963

(b) Technology and the Academics. Macmillan, 1958.

BARKER, Ernest: Universities in Great Britain.

BOLINGER, Dwight, L.: Who is intellectually Free? The Journal of Higher Education. Vol. XXV, Dec. 1954.

COETZEE, J. Chr.: Ons Universiteit, sy grondslag en beginsel en die Vryheidsbeginsel. Koers, Junie 1954

CONGHEY, John Walton: The Practical Defence of Academic 
Freedom. American Association of University Professors Bulletin. Vol. 38, No. 2, 1952.

DE KIEWIET, C. W.: Academic Freedom. University of Cape Town, 1961.

DENT, H. C.: Universities in Transition. Cohen \& West, 1961.

DIEPENHORST, I. A.: De geprangde Universiteit. Keurink en Zoon N.V., Utrecht, sonder jaartal.

EDITORIA COMMENTS: Academic Freedom versus Intellectual Freedom. The Journal of Higher Education. Vol. XXIV, Nov. 1953.

GUSTAD, John W.: The complete academician. Teachers College Record. Vol. 65, No. 2, November 1963.

HASKINS, Charles Homer: The Rise of Universities. Great Seal Books, Cornell University Press, 1923 en 1959.

JOY, Charles, R.: A fighting University. American Association of University Professors Bulletin, Vol. 38, No. 2, 1952.

MAC IVER, Robert M.: Academic Freedom in our Time. Columbia University Press, N.Y., 1955

MALLET, Sir Charles: A History of the University of Oxford. Methuen, 1924.

PROKOFIEV, M. A., Chilikin, M. G. \& Tulpanov, S. I.: Higher Education in the U.S.S.R., Educational Studies and Documents, No. 39, Unesco.

RAIT, Robert S.: Life in the Medieval University.

STOKER, H. G.

(a) Apartheid and University Freedom. Race Relations Journal. Vol. XXIV, No's 3 and 4, July-Dec. 1957.

(b) Intellektuele Vryheid. Die Gereformeerde Vaandel. Deel II, No. 7, Julie 1934

(c) Een en ander oor Menslike Vryheid. Oordruk uit Festschrift - H. J, de Vleeschouwer, Pretoria. 1960.

VAN DEN HAAG, Ernest: Academic Freedom and its Defence. Phi. Delta Kappan, Vol. XXXVI, No. 3, Des. 1954.

WOLTJER, J.: Vrijheid, de levensvoorwaarde voor het hooger onderwijs. J. A. Wormsen, Amsterdam, 1894.

WOODBURNE, L. S.: Universities and the price of Freedom. American Association of University Professors Bulletin, Vol. 38, No. 2, 1952.

METZGER, Wlater P.: Academic Freedom in the Age of the University. Columbia University Press, N.Y., 1955. 